\title{
The Investigation Problems of the Chronicle Narrative
}

\author{
Ivo Pospíšil (Brno)
}

\begin{abstract}
The author of the present study deals with the chronicle both as a genre structure and as a type of a narrative which brings new problems concerning the specific genre itself, its structure and narrative strategy which might be applied to it, and, at the same time, the general problems of the theory of narration. The author asks several crucial questions trying to answer them with the help of a case microstudy: The chronicle is still being revitalised in the context of the varying social situations. The chronicle genres express, above all, the character of national literature and national narrative modes, for example, Russian skaz or Polish gaweda. The most important fact is the ability of the chronicle to create various poetological formations along with the ability to create loose genre valences in a similar manner to chemical elements. Therefore the chronicle represents a specific node of the theory of prose/plot, sujetology.
\end{abstract}

\section{Key words}

chronicle as a genre and narrative structure; chronicle and the general problems of narratology; chronicle as a complex narrative structure; chronicle as a recapitulation of the past for axiological evaluation

\section{Abstrakt}

\section{Výzkumné problémy kronikového narativu}

Autor přtomné studie se zabývá kronikou jednak jako žánrovou strukturou, jednak jako typem vyprávění, jež přináší nové problémy, které se týkají tohoto zvláštního žánru jako takového, jeho struktury, narativní strategie, jež by měla být aplikována, a současně obecných problémů teorie vyprávění. Autor klade několik stěžjních otázek, které se pokouší zodpovědět pomocí prípadových mikrostudií. Kronika se stále oživuje v souvislsosti s měnící se společenskou situací. Kronikální žánr vyjadřuje především charakter národní literatury a národní vyprávěcí způsoby, napřiklad ruský skaz a polskou gavendu. Nejdůležitější je schopnost kroniky vytvářet rưzné poetologické formace spolu se schopností vytvářet volné žánrové valence podobně jako chemcké prvky. Proto kronika předstsvuje specifický modus teorie prózy/syžetu - syžetologie.

\section{Key words}

kronika jako žánrová a vyprávěcí struktura; kronika a obecné problémy naratologie; kronika jako komplexní vyprávěcí struktura; kronika jako rekapitulace minulosti pro axiologické posouzení 
The chronicle as a genre can be characterised by the dominant space complex:

1. The plot of the chronicle is organised as a chronological sequence based on the principle of one temporal line with the less developed category of causality.

2. The space of the chronicle is defined in opposition to the "great world". The motion of the plot from the locality to the "great world" is characterised as the space chronicle pulsation. The chronicle is conceived as the entity which has been changed in the course of history in a similar way as the epopée or the epistolary novel which have lost their systemic and functional character. ${ }^{1}$

The limits of the wide and narrow conception of the genre can be explained by means of the interpretation of the conflict between the genre and the creative method: the genre overcomes the creative method with the help of the new thematic and morphological units; it forms the basis of another genre. The tension between the genre and its method is represented by the liquidation of the method or by the co-existence of both counterparts; this leads to the typology of the chronicle which moves from the analistic record up to the synthesis of the novel and the chronicle (chronological) depictions. The chronicle vision of the world can be defined by the ambivalent chronicle time and the breaking of time. The $19^{\text {th }}$-and the $20^{\text {th }}$-century chronicle often represents a genre mixture of the chronicle, the dramatic novel and the descriptive novel or the myth in which the chronicle functions as a specific genre background. The space of the chronicle is the

1 The author of the present contribution has been dealing with the chronicle in general in many books and separate studies, e. g.: Man's Fate in Space and in Time (The Modifications of the Chronicle Model in N. S. Leskov and K. V. Rais). Opera slavica 1991, 1, p. 44-49; The Hidden Kernel of Paradox: the Chronicles of Anthony Trollope and Nikolai Leskov. Germanoslavica. Zeitschrift für germano-slawische Studien 7 (12), 2000, Nr. 1, p. 35-40; Ruská románová kronika (Př́spěvek k historii a teorii žánru). Brno: Univerzita J. E. Purkyně, 1983; Labyrint kroniky. Pokus o teoretické vymezení žánru. Brno: Blok, 1986; Ruská románová kronika a utilitarismus. Československá rusistika 1982, 3, p. 114-119; Románová kronika a socialistická literatura. Slavia 1983, seš. 2, p. 131-139. Románová kronika jako žánrové východisko. SPFF BU, D 31, 1984, p. 49-56. Idyla, elegie, kronika a moderni literatura. SPFF BU, D 32, 1985, p. 197-201; Powieść-kronika. Zagadnienia rodzajów literackich, z. 1 (65), t. XXXIII, p. 121-125; Žánrové metamorfózy v středoevropském kontextu. Sv. I. Co-editor and co-author Libor Pavera. Brno: Istenis, 2003 (I am the author of the following parts: Na úvod - together with Libor Pavera Literární žánry a genologie: jistoty a hledání, p. 8-36; Kronika, p. 47-52; Cestopis jako faktor dynamizace, pohybu poetiky a žánrových systémů, p. 70-79); Moderni (románová) kronika jako umělecká forma. In: Filolohični seminary. Chudožnja forma, vypusk 8. Kyjiv: Kyjivs'kyj Nacional'nyj Universytet imeni Tarasa Ševčenka, 2005, p. 68-74; Powieść-kronika. In: Słównik rodzajów i gatunków literackich. Pod redakcją Grzegorza Gazdy i Słowini Tyneckiej-Makowskiej. Kraków: Universitas, 2006, p. 572-575 (translated by Krystyna Kardyni-Pelikánová); Roman v novellach i roman-chronika (Zametki o differenciacii russkogo sovetskogo romana). Ruský jazyk 1981, 2, p. 49-54; Sujetkausalität und Romanchronik. Zeitschrift für Slawistik, 1984, 3, p. 421-434; Smysl i kontekst žanrovoj konvergencii mifa i chroniki. Zagadnienia rodzajów literackich, 1992, 2, p. 69-77; Tekučest' istorii i filosofija chronikal'nych struktur v russkoj literature. In: Idea i komunikacja w języku i kulturze rosyjskiej. Pod redakcją Andrzeja Dudka. Kraków: Wydawnictwo Uniwersytetu Jagiellońskiego, sine, 2011, p. 139-153; Jindřich Zogata - básnik vzdorných cest. Brno: Česká asociace slavistů - Tribun EU, 2011; Kronikálni lokalita: tradice a současnost. In: Cesty k dnešku. Živé podněty a tradice ruské a sovětské literatury. Praha: Univerzita Karlova, 1983, p. 241-253; Studie o literárních směrech $a$ žánrech. Banská Bystrica: Katedra slovanských jazykov, Filologická fakulta, Univerzita Mateja Bela, 2004; Ruský román znovu navštívený. Historie, uzlové body vývoje, teorie a mezinárodní souvislosti: Od počátků k výhledu do současnosti. Ed. Jaroslav Malina. Brno: Akademické nakladatelství CERM v Brně - Nakladatelství a vydavatelství NAUMA v Brně, 2005; Pátráni po nové identitě. Rusistické a vztahové reflexe. Brno: SvN Regiony - Středoevropské centrum slovanských studií, 2008; Srovnávaci studie (Komparatistika, slavistika, rusistika a česko-slovenské souvislosti). Trnava: UCM, 2008. 
expression of the temporal dominant: the ambivalent conception of the chronicle time is - rather paradoxically - the main presupposition of its cohesion and stability as the emblems of the finality and the infinity of existence. ${ }^{2}$

The spatio-temporal relations in the chronicle form the structure of the plot as the expression of the compromise between the chronicle and other novel structures. I termed them dominant layers reflecting the chronicle pulsation, the catenary ones expressing the chains of endless artistic details trying to completely disintegrate the compact literary entity and the formative episodes tending towards the dramatic completion of the plot. The details are not, however, the dominant features of the works of one or two authors only: their disingrating function can be found also in the great novels by Leo Tolstoy.

The limits of the wide and narrow conception of the genre are explicated by means of the interpretation - as mentioned above - of the conflict between the genre and its creative method; the genre overcomes its method with the help of the new thematic and morphological unity forming the basis of another genre. The tension between the genre and its creative method is represented by the following processes: 1) the liquidation of the metod; 2) The genre and its creative method do not eliminate each other, they co-exist as counterparts. The chronicle is represented, due to these conclusions, by the following types:

1) The chronicle - the original of the analistic record characterized by the chronological order of the depicted events.

2) The novelized chronicle - the form of the genre which gradually destroys and eliminates the chronological sequence creating a new type of narrative structure which accentuates the function of entertainment.

3) The chronicle written in the form of the novel - this form appears at the beginning of the 19th century and represents, at the same time, the synthesis of the chronicle and the novel based on the dialogue of the chronicle locality and "the great world".

4) The chronicle novel - the form of the genre in which the chronicle itself is a mere part of another structure (e. g. chronicle as part of the mythological novel, a specific narrative structure, for example, with an unreliable narrator etc.

The chronicle in all its genre forms has a specific philosophical background, genre traditions and the character of the plot. The dominant feature of its philosophical background is connected with its dialogue with utilitarianism. The basis of the dialogue is manifested by the "layers of calmness" contrasting with the dynamic plot of the picaresque novel. It is a special type of literature going back to ethological tradition and ethnographical pictures, e. g. in Spanish literature (costumbrismo). The utilitarian conception of the

2 I have been dealing with the chronicle genre since 1974 when I started to write my diploma thesis about Nikolay Leskov, a Russian $19^{\text {th }}$-century prose writer. The literary material I exploited was quite wide including several national literatures of the classical and modern periods., e. g. S. T. Aksakov, N. S. Leskov, M. E. Saltykov-Shchedrin, M. Gorky, J. Bunyan, J. Froissart, Nestor, Kosmas, V. Hájek, Ch. Aitmatov, M. Alemán, H.de Balzac, T. Bibiluri, Ch. Dickens, K. Fedin, L. Leonov. N. Ginzburg, J. Brězan, K. Hamsum, G. Karaslavov, B. Illyés, I. Levin. J. Kozák, S. Lewis, M. Majerová, Th. Mann, Gabriel García Márquez, V. T. Narezhny, A. Jírásek, W. Raabe, B. Říha, G. Stein, A. N. Tolstoy, A. Trollope, G. Uspensky etc. 
morals is opposed by a wider concept of ethical principles (literary protagonists may even act against their own interests); the poetic character of the chronicle creates a new type of individual behaviour ovecoming the barriers of bourgeois individualism. The dialogue between the chronicle genre and the concept of utilitarianism is represented by the themes of "danger of supertension" (unnecessary education, psychic stresses in private life) and in the layer of reminiscences reflecting the life and work of a writer which express similar ideas.

The genre tradition of the chronicle is closely associated with the idyllic and elegiac background. The idyll and the elegy in the chronicle form an inseparable unity in the framework of antinomic pairs (the old - the new, home - world, nature - culture), in the idyllic and elegiac character and their vision of the world, "the golden age" and grief and disillusionment.

The plot of the chronicle is characterized - see the above-mentioned characteristics - by the existence of the following three lines I termed in the following way:

1) The dominant ones which contain fundamental ideas, themes and basic philosophical and ideoligical principles; 2) the formative ones which form tbe plot due to the model of the dramatic novel; 3) the catenary ones which desintegrate the plot. The relations of the causality and the structure of the story and of the plot are then completed by anticipation. Referring to Zdeněk Mathauser's concept ${ }^{3}$, the chronicle structure has a specific function. In general, causality and anticipation influence each other; the causality, on the one hand, limits the range of the anticipation, the anticipation, on the other, affects the causality of the plot, strenthens or does not strengthen the connections and valences of singular elements. The chronicle is typical of the struggle between anticipation and its weak causal presuppositions. Due to the results of the struggle the author speaks of the method of the "gradual integration" of the lot and that of the "global integration". ${ }^{4}$

The problems of the investigation of chronicle narration are closely connected with the natural movement of the genre towards other genres trying to form a more complex genre entity as mentioned above. The rise of the chronicle in general as well as in its various genre modifications have their significant social aspects: they usually appear at the crossroads of the social development, after important, turning, critical events, in the core of the revolutionary or counter-revolutionary processes demonstrating the appeal of looking, glancing back, providing time for contemplating, reflecting, revising or re-evaluating the past events and the future perspectives.

One of the most important problems of the chronicle investigation is the character of the genre convergences, the realization of the chronicle genre and the role of the chronicle nowadays, including mass literature, postmodernist writings and their poetics, traditional realistic novels with some traces of preromantic poetic structures. When in-

3 MATHAUSER, Zeněk: Literatúra a anticipácia. Bratislava: Tatran, 1982. See also my monograph The Range of the Genre (Rozpětí žánru. Brno: Sprint Print, 1992).

4 See the crucial theses of the chronicle as a genre in my monograph Labyrinth of the Chronicle (Labyrint kroniky. Brno: Blok, 1986). 
vestigating the chronicle I have always asked the crucial questions, expressed dominant theses, anwers and reactions:

1) Is the chronicle only an issue of the past? No, the chronicle is still being revitalised due to the social situation.

2) What are the comparative aspects of the chronicle novel? The chronicle genres express, above all, the character of national literature, national narrative modes (Russian skaz, Polish gawęda).

3) What is the position of the chronicle in world literature? It provides the most productive prose modifications.

4) What is the evolutionary trajectory of the chronicle? I sometimes speak of the movement in waves I"wave theory" of the evolution of the chronicle).

5) Is the chronicle a productive basis of the development of modern prose? The most important fact is the ability of the chronicle to create various poetological formations, the ability to create loose genre valences like chemical elements.

6) The chronicle is a complex construction of different narrative structures.

7) The chronicle as a node of the theory of prose/of the plot: "sujetology"

To sum up: the historical reasons for the apprearance of the chronicle: to preserve the vestiges of historical events and to recapitulate the past as a source of information for axiological evaluation.

As an example let me add a short sample, a sort of a concise case study of two chronicle phenomena I once analysed in one of my articles. ${ }^{5}$

Let us go back to the characterization of the chronicle as a genre. The chronicle vision of the world may be defined by the ambivalent chronicle time and the breaking of time. The $19^{\text {th }}$-and the $20^{\text {th }}$-century chronicle often represents a genre mixture of the chronicle, the dramatic novel and the descriptive novel or the myth in which the chronicle functions as a specific genre background. The space of the chronicle is the expression of the temporal dominant: the ambivalent conception of the chronicle time is - rather paradoxically - the main presupposition of its cohesion and stability as the emblems of the finality and the infinity of existence.

The spatio-temporal relations in the chronicle form the structure of the plot as the expression of the compromise between the chronicle and other novel structures. There are dominant episodes reflecting the chronicle pulsation (the term is mine, first used in my book Ruská románová kronika, 1983, p. 24-25).

While the West Europeans, the Americans and the Russians themselves long ago declared the chronicle the central genre in Nikolai Leskov's creations, it is quite rare to find a similar genre approach in Anthony Trollope's criticism. The reasons for this are rooted in different traditions of English literary criticism accentuating the social background and the psychological depiction; at the same time it is also due to the differences in the genre structure itself in general and in the different conception of the chronicle genre in particular.

5 POSPÍŠIL, Ivo: The Hidden Kernel of Paradox: the Chronicles of Anthony Trollope and Nikolai Leskov. Germanoslavica. Zeitschrift für germano-slawische Studien 7 (12), 2000, Nr. 1, p. 35-40. 
Anthony Trollope (1815-1882) was one of the first sharp critics of W. M. Thackeray (his monograph was published in 1879) though he regarded himself as his disciple; Thackeray's approach to the construction of the plot differed a great deal from that of Trollope's: what is considered to be Trollope's weakness, i. e. decorativeness, ornamental depictions etc., represent the most characteristic features of the genre he cultivated - the chronicle. ${ }^{6}$

Nikolai Semenovich Leskov (1831-1895) tended towards the chronicle after his artistic and political failure in writing traditional novels and the novels of the dramatic type. ${ }^{7}$

The artistic position of both writers was rather exceptional and peculiar. Trollope found himself beyond the boundary of traditional Romanticism and realism with his decorative and detailed depictions, Leskov (though he used to return to the model of the dramatic novel of Balzac's kind (Соколий перелет, 1883; Чортовы кукль, 1890) - cultivated the frame chronicle containing the skaz narratives as its thematic and ideological kernel.

6 Anthony Trollope came of a bourgeois London family: his mother Frances Trollope (1780-1863) devoted her writing both to the social conditions in the U.S.A. (especially to the slavery) where she lived for 4 years, and to the life of the English working class in the mid $19^{\text {th }}$ century (The Life and Adventures of Michael Armstrong, the Factory Boy, 1840). Trollope wrote his novels with regular relentlessness; he became the author of 47 novels mainly based in the chronicle structures. Though he is regarded as one of the minor Victorian novelists together with Charles Reade (1814-1884) and William Wilkie Collins (1824-1889), his art of writing, especially his cultivating the chronicle structure with elaborate depictions anticipates modernist poetics embodied in the works of Henry James, James Joyce and Marcel Proust. The success of his novel The Warden (1855) encouraged him to create a series of novels with the central position of the fictitious town Barchester (reminding of the old town of Salisbury): Barchester Towers (1857), Doctor Thorne (1859), Framley Parsonage (1867), The Small House at Allington (1864) and The Last Chronicle of Barset (1867). In the so-called political novels he described the stability and dynamism of Victorian society which suffers from the conflict between the archaic, patriarchal way of life and the new, aggressive bourgeois forces breaking all moral rules: Can You Forgive Her (1864-1865), Phineas Redux (1874), The Prime Minister (1876), The Dukes' Children (1880). Unlike many of his contemporaries, Trollope succeeded in synthetising his moralising approach with the elaborate depictions based on the chains of artistic details. He was a minor British author, a sort of a literary outsider, but at the same time his novels were very popular even in the $20^{\text {th }}$ century: the reason for his popularity might root in the nostalgia of aristocratic readers and in his art of detailed depiction disintegrating the compact plot leading to the fragmentary, shattered structure of the modernist novel.

$7 \quad$ His first prose writings were typical Russian short stories about travelling with colourful portrayals (Pa3бойник, 1862; Овиебык, 1863) or criminal stories with hatred, jealousy and murders (Леди Макбет Миенского уезда, 1865). According to his own experience with radical elements the ideology which he himself originally (in the 1850's) shared, he wrote a series of "angry", antinihilist novels (Некуда, 1864; Обойденные, 1864; На ножах, 1871), but at the same time he cultivated with success the chronicle patterns, such as Островитяне (1866) dealing with the St. Petersburg German minority facing the new social dynamism and immorality. But the climax of his artistic creation is usually connected with his chronicles Cmapure годы в селе Плодомасове (1869), Соборяне (1872) and Захудальй род (1874). The genre shift which has become evident in Leskov's works since the end of the 1860's has a dual structure oscillating between synthesis and disintegration: in the beginning there were short stories, later he attempted at the dramatic and chronicle novels and then he again disintegrated the major novel and chronicle structures into a variety of minor prose genres the variability of which is incredibly rich (in Russian: спиритический случай, рассказ на могиле, полунощное видение, заметки неизвестного, секрет одной московской фамилии, отрывки из юношеских воспомина-ний, геральдический казус, буколическая повесть на историчес-кой канве, рапсодия, пейзаж и жанр, легенда, сказка) accen-tuating the thematic attractiveness and mysterious and adventurous aspects of narration. 
Trollope's chronicle structure moves from the spatial model to the personal or generational pattern as it is signalled by the titles: Bar-chester Towers, The Small House at Allington - The Warden, Cousin Henry, The Duke's Children. The narrative structure is not so complicated as in Leskov's novels; at the same time it is similarly divided into short chapters with colourful titles reflecting the dynamism of the narrative and simultaneously representing the microgenre gallery (Barchester Towers): A Morning Visit (depiction), Slope versus Har-ding (conflict), The Widow's Suitors (portraits) and the Bishop Sits Down to Breakfast and the Dean Dies (annotation). Trollope's work with the chapters of the chronicles reminds of Leskov's principle of serialisation (A Love Scene, Another Love Scene). Leskov is, however, more conscious of the importance of serialisation using even the proverbial net (С вечера девушка, К полуночи молодушка, Ко белу свету хозяюшка) or the record of an adventurous plot (Погоня, Девичий след, Необъяснимые явления увеличивают страх) - see the chronicle Старые годы в селе Плодомасове. While Trollope is stronger and more ellaborate in psychological depictions, Leskov stresses the complicated narrative structure, usually the skaz narration in the chronicle frame. Both Trollope and Leskov are masters of literary portrayals.

The role of artistic details is dominant both in Trollope and in Leskov: the details are the elementary constructional parts of the narrative forming endless chains which suppress the importance of the dramatic plot and weaken the dramatic plot and weaken the role of psychological introspection; the love of details has a function of the emblem of "old times" contrasting with the utilitarianism of the new, dynamic, pragmatic owners. The disintegration of the old world of patriarchal virtues is associated with the fall of the world of feelings and emotions. The paradoxical feature of both Trollope's and Leskov's work is its stability and ideological conservatism which give rise to the new poetic formations. Both works may be characterised by the tendency towards peace and harmony; they are extremely realistic, they reached the limits of realistic poetics and tried to penetrate - so to say - beyond the mirror; they attracted their modernist followers and inspired them: it is evident that both Trollope and Leskov were rediscovered by modernist movements in England and in Russia.

Both Trollope and Leskov have several different faces: one is romantic, patriarchal (Trollope's love of "old, merry England“ and its scenery and architecture, Leskov's love of the Russia under Nicholas I), the other realistic (artistic details and portrayals), the third is their potentiality of ambivalence (peculiarity, strangeness) damaging the relatively stable net of aesthetic and ethical values, the world of the $19^{\text {th }}$-century rational and emotional certainty. The peculiarity of both authors is also connected - obviously by chance - with their strange relations to Bohemia and to the Czech milieu; they are characterised by ambivalence and alienation. Trollope's knowledge of the country is very vague and incorrect while Leskov knew the area and the culture from the experience of his own (see his translations from Czech - Božena Němcová, J. V. Frič; on the other hand he permitted to publish his "immortal" works in all languages except Czech, because he did not like the language).

The two authors used the transitional genre formation (chronicle) which always signals the situation of crisis, social and artistic unrest and motion. The hidden kernel of 
their works contained the destruction of the rational, dramatic ballance typical of the realistic $19^{\text {th }}$-century novels though the chains of portraits and artistic details which functioned as emblems connecting the major message of their artifacts instead of the dramatic plot - opened the way to the reduction of the direct psychological analysis - the tendency towards the weakening of the $19^{\text {th }}$-century psychologism was obvious.

Both Trollope and Leskov stood at the end of one literary epoch bearing its death in their poetics; on the other hand, their cultivated work reflecting the conflict of the old world and the generations of newcomers is an emblem of eternal return and eternal renewal of art and its paradoxical character: the stability may provoke dynamism, the hidden kernel of harmony may evoke a revolutionary shift of emphasis, the old-fashioned character may be a gate leading to modernism.

The preceding comparative example demonstrates the connection of the relatively stable genre structure and its dynamic potentiality realised by the authors themselves. The impact of structuralist and later receptionist approaches stressing the category of the text and that of the reader suppressed the original significance of the author. The writer as a real creator of a literary artefact is a crucial node and crossroads of all the factors in literary creation and reception. The restoration and revitalization of a new concept of the author has to be understood as a completion to the hyperbolized, exeggerated, overestimated reader. As the reader becomes the author and the author is allowed to enter his work and work only as a reader, the author himself/herself may function as a complex reader transforming his experience into an active literary creation converting, transforming his own psychic and existential situation into a literary artefact. The author in all his aspects cannot be ignored or suppressed by the text and the reader, by a wider concept integrating literature into culture and, consequently to free literature from its specific characteristics. ${ }^{8}$

The case of the chronicle in all its modifications may function as a good investigation area for both the theory of literature in general and for the history and theory of literary genres which in some European countries are called "genology" (Paul van Tighem's term "genologie" goes back to $1938^{9}$ ).

\section{References to some of the author's books and studies devoted to the chronicle}

POSPÍŠIL, Ivo: Man's Fate in Space and in Time (The Modifications of the Chronicle Model in N. S.

Leskov and K. V. Rais). Opera slavica 1991, 1, p. 44-49.

POSPÍŠIL, Ivo: The Hidden Kernel of Paradox: the Chronicles of Anthony Trollope and Nikolai Leskov.

Germanoslavica. Zeitschrift für germano-slawische Studien 7 (12), 2000, Nr. 1, p. 35-40.

8 See POSPÍŠIL, Ivo: The Personalistic Approach as a Bridge. Slavica litteraria 20, 2017, 1, p. 21-29.

9 TIEGHEM, Paul van: La question de genres littéraires. Helicon, t. 1, fasc. 1-3, Amsterdam - Leipzig, 1938. 
POSPÍŠIL, Ivo: Ruská románová kronika (Př́spěvek k historii a teorii žánru). Brno: Univerzita J. E. Purkyně, 1983.

POSPÍŠIL, Ivo: Labyrint kroniky. Pokus o teoretické vymezeni žánru. Brno: Blok, 1986.

POSPÍŠIL, Ivo: Ruská románová kronika a utilitarismus. Československá rusistika, 1982, 3, p. 114119.

POSPÍŠIL, Ivo: Románová kronika a socialistická literatura. Slavia, 1983, 2, p. 131-139.

POSPÍŠIL, Ivo: Románová kronika jako žánrové východisko. SPFF BU, D 31, 1984, p. 49-56.

POSPÍŠIL, Ivo: Idyla, elegie, kronika a moderni literatura. SPFF BU, D 32, 1985, p. 197-201.

POSPÍŠIL, Ivo: Powieść-kronika. Zagadnienia rodzajów literackich, z. 1 (65), t. XXXIII, p. 121-125.

POSPÍŠIL, Ivo: Moderni (románová) kronika jako umělecká forma. In: Filolohični seminary. Chudožnja forma, vypusk 8. Kyjiv: Kyjivs'kyj Nacional'nyj Universytet imeni Tarasa Ševčenka, 2005, p. $68-74$.

POSPÍŠIL, Ivo: Powieść-kronika. Heslo. In: Słównik rodzajów i gatunków literackich. Pod redakcją Grzegorza Gazdy i Słowini Tyneckiej-Makowskiej. Kraków: Universitas, 2006, p. 572-575 (translated by Krystyna Kardyni-Pelikánová).

POSPÍŠIL, Ivo: Roman v novellach i roman-chronika (Zametki o differenciacii russkogo sovetskogo romana). Ruský jazyk, 1981, 2, s. 49-54.

POSPÍŠIL, Ivo: Sujetkausalität und Romanchronik. Zeitschrift für Slawistik, 1984, 3, p. 421-434.

POSPÍŠIL, Ivo: Smysl i kontekst žanrovoj konvergencii mifa i chroniki. Zagadnienia rodzajów literackich 1992, 2, 69-77.

POSPÍŠIL, Ivo: Tekučest' istorii i filosofija chronikalnych struktur v russkoj literature. In: Idea i komunikacja w języku i kulturze rosyjskiej. Pod redakcją Andrzeja Dudka. Kraków: Wydawnictwo Uniwersytetu Jagiellońskiego, sine, asi 2011, s. 139-153.

POSPÍŠIL, Ivo: Jindřich Zogata - básnik vzdorných cest. Brno: Česká asociace slavistů - Tribun EU, 2011.

POSPÍŠIL, Ivo: Kronikálni lokalita: tradice a současnost. In: Cesty k dnešku. Živé podněty a tradice ruské a sovětské literatury. Praha: Univerzita Karlova, 1983, s. 241-253.

POSPÍŠIL, Ivo: Studie o literárních směrech a žánrech. Banská Bystrica: Katedra slovanských jazykov, Filologická fakulta, Univerzita Mateja Bela, 2004.

POSPÍŠIL, Ivo: Ruský román znovu navštívený. Historie, uzlové body vývoje, teorie a mezinárodni souvislosti: Od počátku k výhledu do současnosti. Ed. Jaroslav Malina. Brno: Akademické nakladatelství CERM v Brně - Nakladatelství a vydavatelství NAUMA v Brně, 2005.

POSPÍŠIL, Ivo: Pátráni po nové identitě. Rusistické a vztahové reflexe. Brno: SvN Regiony - Středoevropské centrum slovanských studií, 2008.

POSPÍŠIL, Ivo: Srovnávaci studie (Komparatistika, slavistika, rusistika a česko-slovenské souvislosti). Trnava: UCM, 2008.

POSPÍŠIL, Ivo: K teorii ruské literatury a jejím souvislostem. Brno: Munipress, 2013. 
prof. PhDr. Ivo Pospíšil, DrSc.

Ústav slavistiky

Filozofická fakulta, Masarykova univerzita

Arna Nováka 1, 60200 Brno, Česká republika

ivo.pospisi@phil.muni.cz

This work can be used in accordance with the Creative Commons BY-SA 4.0 International license terms and conditions (https://creativecommons.org/licenses/by-sa/4.0/legalcode). This does not apply to works or elements (such as image or photographs) that are used in the work under a contractual license or exception or limitation to relevant rights. 